Marko Kerševan, Ljubljana

\title{
IVAN CVITKOVIĆ IN POKLICNI ETOS SOCIOLOGA RELIGIJE
}

Ivanu Cvitkoviću ob 75-letnici

Svoj prispevek k počastitvi jubileja dragega kolega iz središča/srca nekdanje Jugoslavije, h kateremu me je povabil oddelek za družbene vede Akademije nauka i umjetnosti Bosne i Hercegovine, bom napisal in poslal v slovenskem jeziku. (Bilo mi je ljubeznivo ponujeno, da ga lahko napišem in pošljem v slovenskem, angleškem ali drugem jeziku.)

V času Jugoslavije smo Slovenci v uradnih, strokovnih in osebnih komunikacijah - razen ob redkih strogo uradnih političnih srečanjih, kjer je bilo poskrbljeno za prevajanje - običajno govorili (in pisali) v neki "jugoslovanski” srbsko-hrvaški mešanici, ki je nastala iz nekaj obveznih šolskih ur v osnovni šoli, pa služenja vojaškega roka, spremljanja filmov, televizijskih in radijskih oddaj, prenosa glasbenih in športnih dogodkov iz jugoslovanskega prostora (razen seveda tistih, ki so imeli posebno srbsko-hrvaško jezikovno izobrazbo onkraj obveznih šolskih ur v osnovni šoli, ali tistih, ki so dalj časa živeli v neslovenskih južnoslovanskih jezikovnih okoljih). Sam sem se takrat pri pisanju največkrat trudil z nekakšno $e$-kavščino (da ne bi delal preveč napak pri razreševanju dilem, kdaj je na mestu e-ja-je, kdaj pa -ije), govoril pa sem raje v ije-kavščini, saj je Slovencem tako rekoč nemogoče pravilno izgovoriti srbski $e$ (če nimajo dobrega posluha pa sploh). Tako govorjenje že takrat ni bilo v čast ne govorcu ne takratni spodobni srbo-hrvaščini. Od tedaj pa so se - kot beremo in slišimo - jeziki in govori nekdanjega jugoslovanskega prostora uradno in spontano tako izdiferencirali, da je srbsko-hrvaško-bošnjaška mešanica za Slovence po eni strani še bolj neizogibna, po drugi strani pa nekdanja "jugoslovanska" jezikovna mešanica naše generacije še bolj nemogoča in nespodobna. Kot vseplošno zagotovilo medsebojne jezikovne enakopravnosti, korektnosti in razumljivosti se danes - kot v Evropi sploh - ponuja angleščina. Mlajše generacije se jo zato in tako tudi vedno bolj poslužujejo. Pa vendar... Ne glede na osebno (ne)znanje angleščine, sam (in 
mnogi iz moje ali njej bližnje generacije) to doživljam(o) kot žalitev skoraj stoletnega (in našega več desetletnega) življenja v skupni državi - kakršnakoli je že v posameznih obdobjih bila - in kot žaljivo ignoriranje dejanske jezikovne bližine južnoslovanskih jezikov in narodov. Vsaj za mojo generacijo in njej blizke bi zato lahko veljalo - ne kot obvezujoča norma, ampak kot legitimna opcija - da vsak govori in piše v svojem jeziku, drugi pa ga poizkušajo razumeti in mu odgovarjati v svojem. Še posebej, kadar se govori o skupnih temah in zadevah.

I.

In taka skupna tema in zadeva je (bilo) "vprašanje religije"; ne vprašanje religije nasploh in abstraktno, ali v katerihkoli njenih vidikih, temveč "vprašanje religije in družbe" v Jugoslaviji. Ob njem in zaradi njega sva se z Ivanom $\mathrm{v}$ davnih šestdesetih letih prejšnjega stoletja (v Zagrebu, na skupnem jugoslovanskem podiplomskem študiju "Teorije religije i ateizma") osebno in strokovno srečala, ob njem in predvsem zaradi njega sva si postala in ostala blizu in vsaj občasno tudi v osebnih stikih ves čas do konca Jugoslavije in po njem, vse do danes. "Vprašanje religije in družbe/družbe in religije" je kot vemo najsplošnejša, pavšalna opredelitev področja/okvirja/vsebine "sociologije religije"; vprašanje religije in družbe v Jugoslaviji je tako ekvivalentno vprašanju sociologije religije v Jugoslaviji, vprašanju jugoslovanske sociologije religije. Opredelitev "v Jugoslaviji”, “jugoslovanski”, ki je v našem primeru nastala kot oznaka za teritorialno razmejitev, za prostorski okvir, ima danes seveda tudi časovno konotacijo, pomeni tudi ali celo predvsem časovni okvir, časovno zamejitev problematike in njene sociološke obravnave. Vprašanje religije in družbe, družbe in religije v Jugoslaviji, je v šestdesetih in sedemdesetih letih združilo vrsto sodelujočih (čeprav tudi razhajajočih se in občasno konkurirajočih si) jugoslovanskih sociologov (religije). Ugledni sociolog kasnejše/"srednje" generacije Dragoljub B. Đorđević je v svoji, po zamisli in izvedbi izjemni knjigi Uzornici i prijani (2008) (i)zbral in skiciral portrete desetih "YU sociologa religije" te prve vrste (med njimi ene sociologinje) ter posredno zarisal tudi kolektivni portret takratne jugoslovanske sociologije religije: Štefice Bahtijarević, Srđana Vrcana, Nikole Duganđija, Jakova Jukića (Željka Mardešića), Marka Kerševana, Nikole Skledara, Esada Ćimića, Sergeja Flereta, Ivana Cvitkovića, Đure Šušnjića. V svojem prispevku bom poizkušal očrtati, kako kot eden iz te vrste/"generacije" (oblikovane in bolj ali manj delujoče in pišoče predvsem v času Jugoslavije) vidim danes specifični doprinos kolege Cvitkovića k "razvoju sociologije religije" - kot je 
natančno pisalo v povabilu ANUBiH - torej brez vnaprejšnjih jugoslovanskih prostorskih in časovnih zamejitev.

\section{II.}

Če od zunaj in na hitro pogledamo književni opus Ivana Cvitkovića - naslove njegovih knjižnih del in bibliografijo avtorjev in del, na katere se sklicuje - smo morda v prvem hipu v zadregi, ali ga lahko označimo kot v prvi vrsti sociologa religije in njegovo delo prvenstveno in večinsko kot "sociologijo religije": Marksistička misao o religiji, Savez komunista i religija, Ko je bio Alojzije Stepinac, Krleža, Hrvati i Srbi, Religije suvremenoga svijeta, Rječnik religijskih pojmova, Sociologija religije, Društvena misao u svetim spisima, Sociologija spoznaje, Konfesija u ratu, Hrvatski identitet u Bosni i Hercegovini, Socijalna naučavanja o religijama, Moj susjed Musliman, Encountering Others, Sociološki pogledi na naciju i religiju, Sociologija obreda, Religija u zrcalu teorija... Toda pobližji pogled/pregled že samih naslovov in njihova struktura take dvome hitro razprši. Ne samo, da ima Cvitković edini od zgoraj omenjene plejade začetnikov Yu-sociologije religije delo z neposrednim naslovom Sociologija religije (med ostalimi se temu s kolegom Sergejem Fleretom samo približava s podnaslovom skupnega dela: Religija in (sodobna) družba: Uvod v sociologijo religije (1995)) tudi ostala njegova dela/naslove je mogoče razvrstiti tako, da postane razvidno, kako je sociologija religije strokovno središče in hkrati vezivo njegovih na prvi pogled raznovrstnih preokupacij. Ob sami Sociologiji religije so tu dela, katerih naslovi govore o specializirani obravnavi posameznih tradicionalnih sestavin sociologije religije: Sociologija obreda, Socijalna naučavanja u religijama ter delo Religija u zrcalu teorija, ki se posebej loteva teoretskih konceptualizacij (kot kažejo že podnaslovi predvsem socioloških). Drugi del njegove v angleškem jeziku izdane knjige Encountering Others je izrecno naslovljen kot Open Questions of the Sociology of Religion in obravnava nekatere metodološke probleme sociološkega raziskovanja pravoslavja, vprašanje religije in globalizacije, sodobne razprave o "povratku religij" ali "povratku k religijam", teme sodobnih diskusij v sociologiji religije. Rječnik religijskih pojmova, Religije suvremenog svijeta in kot rečeno Religija u zrcalu teorija nudijo neobhodno širše religiološko znanje, brez katerega ni zaresne sociologije religije oziroma obravnave vprašanja "religija in družba". Dela Sociološki pogledi na naciju i religiju, Moj susjed musliman, Hrvatski identitet u Bosni i Hercegovini, Konfesija u ratu, prvi del knige Encountering Others, se posvečajo ključnim vprašanjem razmerja "religije in družbe", ki/kot ga je avtor konkretno doži- 
vljal v svojem (našem) prostoru in času in ki ni samo omogočal, ampak tudi zahteval specifično in angažirano sociološko obravnavo že v času Jugoslavije, še posebej pa v večnacionalni in večreligijski BiH. V to vrsto del sodijo tudi knjige Marksistička misao i religija, Savez komunista i religija, Bilješke o religiji, iz osemdesetih let. Dela obravnavajo takrat aktualne/akutne vidike razmerja družba-religija, ki/kot jih je obeleževalo ideološko in politično soočenje marksizma/Zveze komunistov in religije $\mathrm{v}$ jugoslovanskem in posebej bosanskem prostoru $-\mathrm{v}$ veliki meri tudi takrat ob temi nacija-religija. $\mathrm{V}$ to navzkrižje sodi po naslovu (in vsebini) navsezadnje tudi Cvitkovićeva knjiga Ko je bio Alojzije Stepinac (1986).

Na prvi (v)pogled nas bi v zadrego lahko spravil tudi izjemno široki diapazon imen avtorjev, na katere se sklicuje in jih citira. A spet samo na prvi vpogled. Resda uvaja celo svojo Sociologijo religije s citatoma Krleže in Konfucija in srečamo v drugih njegovih delih na podobnih mestih Čehova, Hemingwaya, Berdjajeva, Einsteina, Kuzanskega, Lincolna, Eleonoro Roosewelt, Kardelja, Kołakowskega, ljudske pregovore, citate iz Biblije in Korana, pa spet in spet Krležo. Toda pobližji vpogled v Sociologijo religije in druga dela pokaže temeljno sociološko zasidranost in usmerjenost Cvitkovićeve obravnave religije (in družbe). Nenazadnje, njegovo najnovejše delo Religija u zrcalu teorija (2016) zgovorno uvaja misel Norberta Eliasa, enega od zdaj že klasikov sociologije po drugi svetovni vojni: "Nijedan čovjek nije na početku, svaki čovjek nastavlja." V tako rekoč vseh navedenih delih najdemo navezave (in izrecno sklicevanje) na klasike sociologije (religije): Comta, Marxa, Durkheima, Webra, Troeltscha, Wacha, Parsonsa, Gurvitcha, Le Brasa; pa na klasike in novejše avtorje sociologije religije iz časa po drugi svetovni vojni do danes: Luckmanna, Bergerja, Luhmanna,Vernona, Boudona, Bourdieuja, Baudrillarda, Hervieu-Leger, Touraina, Baumana, Eagletona, Casanove, Lubbeja, Charlesa Taylorja; tu so vsi domači, jugoslovanski sociologi religije iz omenjene deseterice in mimo nje: Pavićević, Vrcan, Ćimić, Šušnjić, Kerševan, Flere, Jukić/Mardešić, Dugandžija, Maštruko, Skledar, Marasović, Đorđević...; tu so za sociologijo religije nepogrešljivi antropologi in religiologi Malinowski, Frazer, Levi-Strauss, Eliade... Ta sociološka konstanta in dominanta je spremljana, dopolnjevana, ilustrirana, tudi problematizirana, s pravim ognjemetom misli in citatov ustanoviteljev religij, sodobnih papežev, klasičnih in sodobnih teologov in filozofov (tudi Žižek ne manjka), predvsem pa pisateljev in pesnikov. Naj še enkrat spomnim na Krležo, katerega misli in citati spremljajo tako rekoč vsa Cvitkovićeva dela, predvsem pa tista, ki se ukvarjajo z njegovo ključno, vozliščno sociološko temo, teoretskimi in praktičnimi vidiki razmerja religija-nacija. Naj na tem mestu poudarim, da so 
Cvitkovićeva dela svojevrstna enciklopedija raznolikega vedenja in različnih vpogledov v svet religij(e), ki jih tradicionalno raznoliko bosansko-hercegovsko okolje omogoča in izziva - predvsem pa potrebuje. In ena od Cvitkovićevih zaslug in tako rekoč uslug svojemu prostoru in ljudem, je, da jim tak kalejdoskop vedenja in vpogledov neumorno ponuja že več desetletij.

\section{III.}

Odločilen za presojo specifičnega Cvitkovićevega prispevka k sociologiji religije pa je njegov izbor in način obravnave ključne problematike njegovega sociološkega in religiološkega dela: nacije in religije / religije in nacije. Ta problematika izstopa tako v ustreznih poglavjih splošnejših del kot je Sociologija religije, v knjigah kot Moj susjed musliman, Hrvatski identitet $u$ BIH ter številnih predavanjih, intervjujih, zapisih, zbranih $\mathrm{v}$ treh zvezkih z naslovom Sociološki pogledi na naciju i religiju. Mesto in teža, ki jo ima ta problematika v različnih Cvitkovićevih besedilih in način njene obravnave kaže, da zanj to ni preprosto ena od formalno-teoretsko nujnih in/ali zanimivih tem sociologije religije, a tudi ne le ena od aktualnih in politično se vsiljujočih tem njegovega prostora in časa. Gre za temo, ki je na presečišču njegovega temeljnega sociološkega vedenja in raziskovanja in njegove njegove temeljne osebne človeške/humanistične, nacionalne in državljanske senzibilnosti. Videli smo že, da Cvitković svoje prikaze, vpoglede in razglede, svoje obravnave tako teoretskih pojmov kot konkretnih pojavov s področja sociologije religije vedno pospremi in komentira z (i)zbranimi mislimi in citati, raznovrstnimi po virih in usmerjenosti: takimi, ki njegovo obravnavo potrjujejo, nadaljujejo, a tudi takimi, ki jo problematizirajo ali ji včasih celo nasprotujejo. Citirane misli in poglede $\mathrm{z}$ druge strani pogosto tudi sam komentira. Vse to srečamo tudi pri obravnavi teme religija-nacija.

Toda prav pri obravnavi te teme se srečamo tudi s Cvitkovićevo izrecno in izrazito osebno opredeljenostjo, zavzetostjo, angažiranostjo. Lahko bi rekli: konstantno in vztrajno angažiranostjo od časa njegovih zgodnjih spisov v socialistični Jugoslaviji do danes. Cvitković ni skrival in ne skriva svoje ateistične opredeljenosti, marksistične teoretske zasidranosti in naravnanosti, svoje hrvaške nacionalnosti. Toda za kar se je s svojim intelektualnim delom zavzemal, ni bila stvar ateizma, marksizma, hrvaštva, njihova "zmaga" ali vsaj uspeh v soočenjih in spopadih z drugimi verskimi, nazorskimi ali nacionalnimi opredelitvami. Angažiral se je za ustvarjanje (ali ohranjanje) pogojev njihovega civiliziranega sobivanja, za medsebojno poznavanje in razumevanje ter sodelovanje ljudi različnih verskih, nazorskih, nacionalnih opredeli- 
tev, za njihovo (mirno, sodelujoče) skupno življenje - konkretno in v prvi vrsti seveda ljudi svojega bosanskega in hercegovskega prostora in časa. Tem pogojem (takega) skupnega življenja je namenjena njegova kritičnost in polemičnost do samo-vase-zaverovanosti, ekskluzivmosti, "fundamentalizma", sektaštva navznoter in nestrpnosti in agresivnosti do drugih - kritičnost in polemičnost do takih usmeritev med ljudmi njegove lastne svetovnonazorske in nacionalne pripadnosti, kot pri drugih (tako znotraj ateizma kot katoliškosti, pravoslavja, islama, tako med versko ali nacionalno neopredeljenimi "komunisti” in "Jugoslovani”, kot med Hrvati, Srbi, Bošnjaki). Temu služi njegovo vztrajno ponujanje religiološkega znanja (o "svoji” in drugih religijah), razkrivanje notranjih protislovij vseh ekstremnih pozicij, sociološka analiza pogojev nastanka, uspeha in družbenih posledic ekskluzivističnih, ekstremističnih in agresivnih usmeritev (še enkrat: tako "lastnih" kot tujih). Prizadeva si skratka, da bi s sociološkim in religiološkim vedenjem sociologije religije (njenim znanjem, pristopi, analizami) prispeval k "srečevanju/srečanju z drugimi” (kot se ustrezno glasi naslov njegovih izbranih spisov v angleščini), ne pa k uspehu/zmagi "naših" v spopadu z "drugimi". V ozadju prizadevanja je seveda prepričanje, da je tako srečanje z drugimi, skupno življenje z drugimi, tisto najboljše tudi za "nas", za našo religijo in nacijo, za ljudi našega svetovnega nazora, naše nacije in religije - ljudi vseh nacij in religij v sodobnosti in perspektivi $\mathrm{BiH}$ in sodobnega sveta sploh. Tako prepričanje in taka usmerjenost je obeleževala že Cvitkovićevo kritiko in polemiko s fundamentalizmom/“sektaštvom" med komunisti/ateisti v času socialistične Jugoslavije, še bolj pa kritiko in polemiko z nazorskim, verskim ali nacionalističnim fundamentalizmom po njenem razpadu.

Tako v enem svojih zadnjih spisov o tej temi konstatira: "Povezanost kršćanstva s nacionalizmom (hrvatskim, srpskim) i islama s bošnjačkim nacionalizmom je balkanska bolest. I ne samo to. Svi se smatraju izabranim. Kakav bi to bio Bog, koji bi radio na favoriziranju jednih na račun drugih?" (Cvitković 2017: 63). Reflektira: "Neki bi rekli da ova 'fuzija' religije i nacionalizma neminovno vodi do politiziranja religije (bar što se tiče nacionalnih interesa i tradicija)" (Cvitković 2017: 64). Presoja in posploši: "Najčešće se sukobljavaju politizirana religija i politička religija (koja je Naciju uzdigla na pijedestal obožavanja, izvršila pobožavanje nacije ... 'odurni nacionalisti koji naciju stavljaju iznad svega', rekao bi Umberto Eco.” (Cvitković 2017: 57).

Davnega leta 1984 je v drugem političnem času in kontekstu - a ob isti temi in v istem prostoru - zapisal: "Savez komunista ne može prihvatiti sektaška i dogmatska stanovišta onih koji hoće 'bitku' s religijom, ometajući, ponekad, religijske zajednice i u radnjama koje su po zakonu i Ustavu dozvoljene" 
(Cvitković 1985: 107). “Sektaštvo je za Savez komunista jednako neprihvatljivo kao i sam klerikalizam... a šta je drugo već sektaštvo uzimanje ateizma (...) kao kriterija(!) moralno-političke podobnosti za obavljanje određenih zanimanja" (prav tam). Klerikalizem "je upravo politiziranje religije”, ki se najbolj pogosto udejanja $\mathrm{v}$ nerazdružnem povezovanju "našega naroda" in "naše vere" (kot ironizira s citati iz Krleževih del, Cvitković 1985: 52-53).

Morda nista odveč dve ilustraciji iste teme iz drugih okolij in časov - ki pokažeta, da nikakor ne gre le za (ne)aktualne "balkanske zadeve". Ob koncu katastrofe druge svetovne vojne in priznanju nemške krivde zanjo so predstavniki Evangeličanske cerkve v Nemčiji v izjavi leta 1947 samokritično zapisali: "Zablodili smo [wir sind in die Irre gegangen], ko smo začeli sanjati o posebnem nemškem poslanstvu (...) s tem smo pripravili tla za neomejeno uporabo politične moči in postavili naš narod na Božji prestol (...). Tako smo zavrgli naše pravo poslanstvo, da z darovi, ki smo jih Nemci prejeli, sodelujemo pri skupnih nalogah ljudstev. Zablodili smo, ko smo začeli vzpostavljati 'krščansko fronto' proti nujnim preureditvam v družbenem življenju (...) Zablodili smo, ko smo menili, da moramo v političnem življenju in s političnimi sredstvi oblikovati eno fronto dobrih proti zlim, svetlobe proti temi, pravičnih proti nepravičnim (...).” (Darmstadtska izjava 1947).

Sam sem leta 1989 ob slovenskih in neslovenskih pojavih iz takrat polpretekle zgodovine zapisal: "Vključevanje Boga v gesla in prakso 'boja za Boga, Narod, Domovino', je ponižalo Boga v enake vrste pogansko božanstvo, pa čeprav najvišje, v kakršno sta bila povzdignjena Narod in Domovina: vsi so enako zahtevali boj, žrtve in žrtvovanja." (Kerševan 1989: 176).

\section{IV.}

Kako bi lahko neposredno odgovorili na zastavljeno vprašanje, $v$ čem je (specifični) prispevek Ivana Cvitkovića sociologiji religije in njenemu razvoju?

Kot prvo: V svojih delih je vztrajno in domiselno predstavljal vso širino in bogastvo spoznanj, pristopov in metod sociologije religije. To je počel v okolju, ki je s svojo raznolikostjo, svojo dinamiko in svojimi blokadami sociologijo religije, njena spoznanja in metode, posebej izzivalo in posebej potrebovalo.

Drugo: sociologom religije (ne le svojega družbenega in verskega okolja!) je dal vzgled, kdaj in kako se morajo sociologija (religije) in sociologi opredeliti in angažirati v imenu svoje stroke, njenih osnovnih izhodišč in spoznanj; kako se morajo (in smejo) angažirati s sredstvi svoje stroke, njenimi spoznanji in metodami. Sociologija religije je nastala in živi iz spoznanja 
raznolikosti religijskih svetov v raznolikosti njihovih družbenih kontekstov in učinkov. Kot taka se ne more sprijazniti s teoretičnim ignoriranjem/negiranjem ali praktičnim odpravljanjem te raznolikosti in/ali proglašanjem zgolj ene različice religije, ali zgolj enega družbenega konteksta, za edino sveto, nedotakljivo in nepresegljivo. Temu ne nasprotuje le zaradi "egoizma stroke", ki pač hoče ohraniti svoj "predmet" in raison svojega obstoja, ampak zaradi svojega spoznanja, da prav ignoriranje, negiranje, nasilno odpravljanje religijskih in nazorskih razlik in/ali njihovo selektivno sakraliziranje - ne pa razlike same - vodi v katastrofe za ljudi in razruši pogoje njihovega sožitja. Kot da ne bi bilo onkraj teh razlik ničesar "naravnega", človeškega, družbenega, božjega, kar bi jih utemeljevalo/opravičevalo in transcendiralo/presegalo hkrati, ničesar, kar bi nasprotovalo - ne razlikam samim, ampak - njihovemu negiranju in/ali njihovi sakralizaciji!

Seveda sociologija religije pri tem spoznanju ni sama, z(a) njo je tako zgodovina družb(e) in religij(e) kot sodobno izkustvo, tisto neposredno, iz prve roke, ali posredovano skozi umetnosti in medije. Delo Ivana Cvitkovića je lahko vzgled, kako se lahko sociologija religije opira na spoznanja in misli drugih strok in drugih avtorjev, drugih okolij in drugih časov. Seveda lahko tak vzgled uspešno sledi le, kdor ima kot Cvitković ustrezno široko znanje in senzibilnost; priznati moramo, da je med nami le malo takih.

Sociologija religije ima s svojim znanstvenim, strokovnim in publicističnim delom le omejen vpliv in domet. Ivan Cvitković je izpričal svojo življenjsko in strokovno vztrajnost in pogum. Gledano od zunaj, lahko rečem(o), da je svojemu izjemno raznolikemu, izjemno občutljivem in hkrati z izjemnimi napetostmi prežetemu okolju dajal tisto, kar je potrebovalo: široka strokovna znanja in znanstvenoraziskovalna spoznanja v službi strpnosti in sožitja. Ni na meni, da presojam, ali je njegovo ožje okolje BiH to njegovo ponudbo in take njegove namene prepoznalo in sprejelo. Lahko pa nekoliko privzdignjeno rečem(o) in zaključim(o) - kot se za jubileje spodobi - da jih bo čas prepoznal in jim dal priznanje. Na en način, če/ko bo na balkanskem prostoru prevladal duh strpnosti, sožitja, mirnega tekmovanja in sodelovanja; na drug način - kot preslišano svarilo - če/ko se bo dogajalo in (spet) zgodilo nasprotno od tega, za kar si je prizadeval. V enem svojih novejših zapisov (iz leta 2013) ni bil optimist: "podjele i udaljenosti među pripadnicima ta tri naroda i tri konfesije su neuporedivo veće nego što su bile prije početka ratova devedesetih" (Cvitković 2017: 66).

Koliko je njegova presoja še aktualna, ne morem reči. Žal me spomni na naše diskusije in medsebojna "uvjeravanja" iz tistih let v takrat še skupni državi, namreč, da se kaj takega (kot že leta 1991 spopadi na Hrvaškem) v 
BiH ne more zgoditi, "saj vsi vemo, kaj bi se zgodilo, če bi se zgodilo”. Toda zgodilo se je: prav to, za kar smo bili prepričani, da se ne bo, ker smo "vsi vedeli, kaj bi se sicer zgodilo". Odločilno ni bilo naše vedenje, niti naše pisanje, pa tudi ne množične demonstracije za mir in sožitje v BiH 1991 - odločilnejši so bili streli na svatbo... (in brezumno sovraštvo ali/in brezumni računi, ki so bili za tem in takimi brezumnimi dejanji). A ne gre pozabiti: "negativni občutki ne eksplodirajo v destruktivne akcije, če jim primanjkujejo besede, formule in argumenti, ki jih lahko nudijo intelektualci" (Czesław Miłosz).

Toda Cvitkovićev vzgled ostaja in bo ostal; vzgled izjemne vztrajnosti, stanovitnosti in intelektualnega poguma pri osebnem prepričanju in etosu svoje/naše stroke - vzgled ne le v BiH in prostorih nekdanje Jugoslavije...

\section{Literatura}

Cvitković, Ivan (2017), Sociološki pogledi na naciju i religiju III, Štamparija Fojnica, Fojnica. Cvitković, Ivan (2016), Religija u zrcalu teorija, Centar za empirijsko istraživanje religije CEIR, Sarajevo.

Cvitković, Ivan (2014), Sociologija obreda, Nacionalna i univerzitetska biblioteka BiH, Sarajevo.

Cvitković, Ivan (2013), Encountering Others (Religious and Confessional Identities in Bosnia and Herzegovina), Yugoslav Society for the Scientific Study of Religion, Niš.

Cvitković, Ivan (2012), Sociološki pogledi na naciju i religiju II, CEIR, Sarajevo.

Cvitković, Ivan (2011), Moj susjed musliman, Školska knjiga, Zagreb.

Cvitković, Ivan (2007), Socijalna naučavanja o religijama, Nacionalna i univerzitetska biblioteka BiH, Sarajevo.

Cvitković, Ivan (2006), Hrvatski identitet u Bosni i Hercegovini - Hrvati između nacionalnog i građanskog, Synopsis, Zagreb / Sarajevo.

Cvitković, Ivan (2005a), Sociološki pogledi na naciju i religiju, Sarajevo, DES.

Cvitković, Ivan (2005b), Rječnik religijskih pojmova, 2. dopunjeno i prošireno izd., DES, Sarajevo.

Cvitković, Ivan (2004), Konfesija u ratu, Svjetlo riječi, Sarajevo.

Cvitković, Ivan (2001), Sociologija spoznaje, DES, Sarajevo.

Cvitković, Ivan (1999), Religije suvremenoga svijeta, Fakultet političkih nauka / Svjetska konferencija religija za mir, Sarajevo.

Cvitković, Ivan (1997), Društvena misao u svetim spisima, vlast. nakl., Mostar / Sarajevo.

Cvitković, Ivan (1996), Sociologija religije, Edicija Univerzitetska knjiga, Ministarstvo obrazovanja, nauke, kulture i sporta, Sarajevo.

Cvitković, Ivan (1991), Krleža, Hrvati i Srbi, Biblioteka posebnih izdanja Oslobođenje public / Institut za proučavanje nacionalnih odnosa, Sarajevo.

Cvitković, Ivan (1986), Ko je bio Alojzije Stepinac, Politička biblioteka, Oslobođenje, Sarajevo.

Cvitković, Ivan (1985), Savez komunista i religija, 2. dopunjeno izd., Politička biblioteka, Oslobođenje, Sarajevo.

Cvitković, Ivan (1980a), Bilješke o religiji, Oslobođenje, Sarajevo.

Cvitković, Ivan (1980b), Marksistička misao i religija, Svjetlost, Sarajevo. 
Doprinos akademika Ivana Cvitkovića razvoju sociologije religije (Povodom 75. godišnjice života)

Darmstadtska izjava 1947 (2019), Stati inu obstati: Revija za vprašanja protestantizma, Ljubljana, št. 30, str. 194-195.

Đorđević, Dragoljub B. (2008), Uzornici i prijani: skice za portret YU sociologa religije, Čigoja štampa, Beograd.

Flere, Sergej - Kerševan, Marko (1995), Religija in (sodobna) družba: Uvod v sociologijo religije, Znanstveno in publicistično središče, Ljubljana.

Kerševan, Marko (1989), Religija in slovenska kultura: ljudska religioznost, civilna religija in ateizem v Sloveniji, Znanstveni inštitut Filozofske fakultete / Partizanska knjiga, Ljubljana. 